\title{
Environmental aspects and economic evaluation of new green hydrolysis method for waste feather processing
}

\author{
Olga Solcova ${ }^{1}$ (D Jaroslav Knapek ${ }^{2} \cdot$ Lenka Wimmerova $^{3} \cdot \mathrm{Kamila} \mathrm{Vavrova}^{4} \cdot$ Tomas Kralik $^{2} \cdot$ Milena Rouskova $^{1}$. \\ Stanislav Sabata ${ }^{1}$. Jiri Hanika ${ }^{1}$
}

Received: 22 November 2020 / Accepted: 16 March 2021 / Published online: 9 April 2021

(c) The Author(s) 2021

\begin{abstract}
In recent years, an increase in the chicken meat process industry has been growing quickly, which brings a large amount of difficult to process waste, chicken feathers. These billions of kilograms create a serious waste problem over the world, furthermore, poultry feather processing is not only particularly difficult but also relatively expensive. In fact, there is no technology suitable for processing such huge quantities of feathers to guarantee sustainable development of the chicken meat industry together with processing of waste feathers. This article introduces a newly designed and original, highly efficient and environmentally friendly method of physicochemical hydrolysis of waste feathers. The hydrolysis is carried out in the presence of a weak organic carboxylic acid; thus, the resulting hydrolysate does not contain any salts or ashes. Therefore, a resulting hydrolysate, which includes a mixture of amino acids, peptides, proteins, glycoproteins and free fatty acids, is suitable for a variety of applications; e.g. as a chondroprotective agent in the treatment of joint diseases, nutrients for crop plants or targeted biostimulants for agriculture. This paper is focused not only on the process scale-up but also on environmental aspects and economic evaluations to bring general view of the process.
\end{abstract}

\section{Graphic abstract}
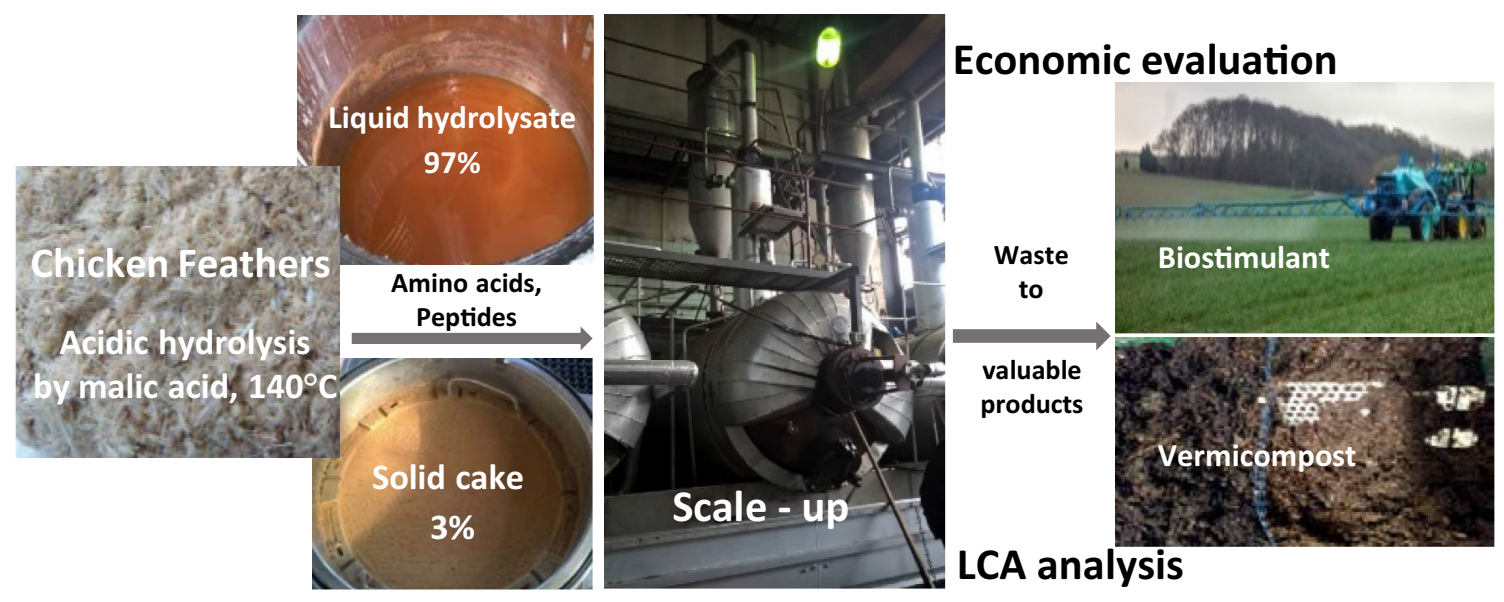

Keywords Animal waste $\cdot$ Hydrolysis of chicken feathers · Green hydrolysate composition · Environmental aspects · Economic evaluation

Olga Solcova

solcova@icpf.cas.cz

Extended author information available on the last page of the article 


\section{Introduction}

The chicken meat process industry has been growing quickly over the whole world (Kanani et al. 2020). Concerning the average consumption per person, chicken meat represents the second position (following pork, which holds the first one) with $41.2 \mathrm{~kg}$ per year in the EU and $59 \mathrm{~kg}$ in the USA, in 2016. Moreover, this consumption rate has a growing tendency; factually, about 5\% annually over the last 15 years (Windhorst 2018). Due to the amount of poultry and especially due to the amount of chicken meat produced, chicken feathers (poultry) are a difficult type of waste with complicated disposal (Tesfaye et al. 2017a, b). There is about $125 \mathrm{~g}$ of feathers per chicken in slaughter weight. This then causes problems with waste disposal both on a global scale (according to the FAO in 2018 about 124 million tons of chicken meat was produced-in carcass weight) and in local conditions of Czech poultry farms. In 2018260 thousand tons of poultry meat in live weight were produced in the Czech Republic, of which about $90 \%$ was chicken meat (Ministry of Agriculture of the CR 2017). Even in the Czech Republic, a considerably large amount of waste (chicken feathers) is difficult to process, its amount can be estimated at about 15 thousand tonnes. These billions of kilograms create a serious waste problem over the world (Nahm and Nahm 2004); furthermore, poultry feather processing is not only particularly difficult but also relatively expensive.

Nevertheless, poultry feathers are rich in keratin protein, which makes them, among others, a good source of nitrogen fertilizer (Joardar and Rahman 2018). The production, purification, and characterization of thermostable-alkaline keratinase from Bacillus halodurans SW-X (keratinase_SW-X) seems to be promising with respect to its applicability towards the production of white chicken feather hydrolysate and bioplastic starch/keratin (Kaewsalud et al. 2020). Hydrolysis of waste feathers (Tesfaye et al. 2017a, b) in turn provides valuable amino acids, proteins and peptides in the mixture with acylglycerols and higher fatty acids. Prepared hydrolysate can be used as a common cosmetic ingredient which increases skin elasticity and moisturization, usually as an additive in shampoos and conditioners. Neutral protein hydrolysates are also valuable for a dermatological use, regenerative medicine, cosmetics, biodegradable food packaging, functional ingredients in food, etc. (Sinkiewicz et al. 2018). Regrettably, commonly applied hydrolysis using a strong mineral acid (Bouhamed and Kechaou 2017) or base (Pahua-Ramos et al. 2017) leads to a necessary subsequent recycling of the process solutions, including neutralization and elimination of undesirable salts. In the literature, there are now dozens of studies mostly focused on the biotransformation of feathers by microorganisms or enzymes, unfortunately mostly in sophisticated treatments suitable for laboratories (Kumar et al, 2011). However, there is no technology that would be suitable to process such huge quantities of feathers into high value-added products. It is, therefore, inevitable to search for a greener bio-waste treatment of a high capacity.

In terms of economic evaluation of the process of hydrolysis of feathers, the valuation of the incoming materialfeathers-plays an important role. It is an application of the principle of opportunity cost, i.e. taking into account the method of current use, respectively, disposal of feathers. Despite various efforts to use feathers for various, often non-traditional purposes, such as thermal insulation (Nar$\cos 2020$ ), acoustic panels (Ansarullah et al. 2018), or ecofriendly bioplastic film (Sharma et al. 2018), its use is problematic and has the character of difficult waste. The burning of feathers is difficult and leads, for example, to a significant amount of NOx emissions (due to the relatively high nitrogen content). The technologies discussed and tested so far (chemical or biological processing of feathers) are not yet in a commercially usable stage (Tesfaye et al. 2017a, b). However, there is no technology suitable for processing such huge quantities of feathers into high value-added products.

This paper deals with an original, highly efficient and environmentally friendly method of physicochemical hydrolysis of waste feathers to obtain amino acids, peptides, proteins, glycoproteins and free fatty acids with their mono-, di- and tri-acylglycerols. The hydrolysis is carried out in the presence of a weak organic carboxylic acid; thus, the resulting hydrolysate does not contain any inorganic salts which are formed when the hydrolysis is initiated by inorganic acids or bases. Thus, the newly designed hydrolysis by malic acid guarantee that the hydrolysate is suitable for applications as a chondroprotective agent in the treatment of joint diseases, similarly as nutrients for crop plants or targeted fertilizers. Therefore, this paper is focused not only on the process scale-up but also on environmental aspects and economic evaluations.

\section{Experimental}

The waste chicken feather hydrolysis (Hanika et al. 2019a, b) initiated by malic acid was performed in batch stirred reactors (having the volume of 2, 25 and $8000 \mathrm{~L}$ resp.) under an inert atmosphere of nitrogen or steam and at elevated temperature in the range of $115-139^{\circ} \mathrm{C}$. The mechanism of feather hydrolysis by malic acid is shown in Fig. 1. Photographs of the reactors are shown in Fig. 2, where (a) represents the reactor of the volume of $2 \mathrm{~L}$, (b) of $25 \mathrm{~L}$ and (c) of $8000 \mathrm{~L}$. 
Fig. 1 The mechanism of feather hydrolysis by malic acid
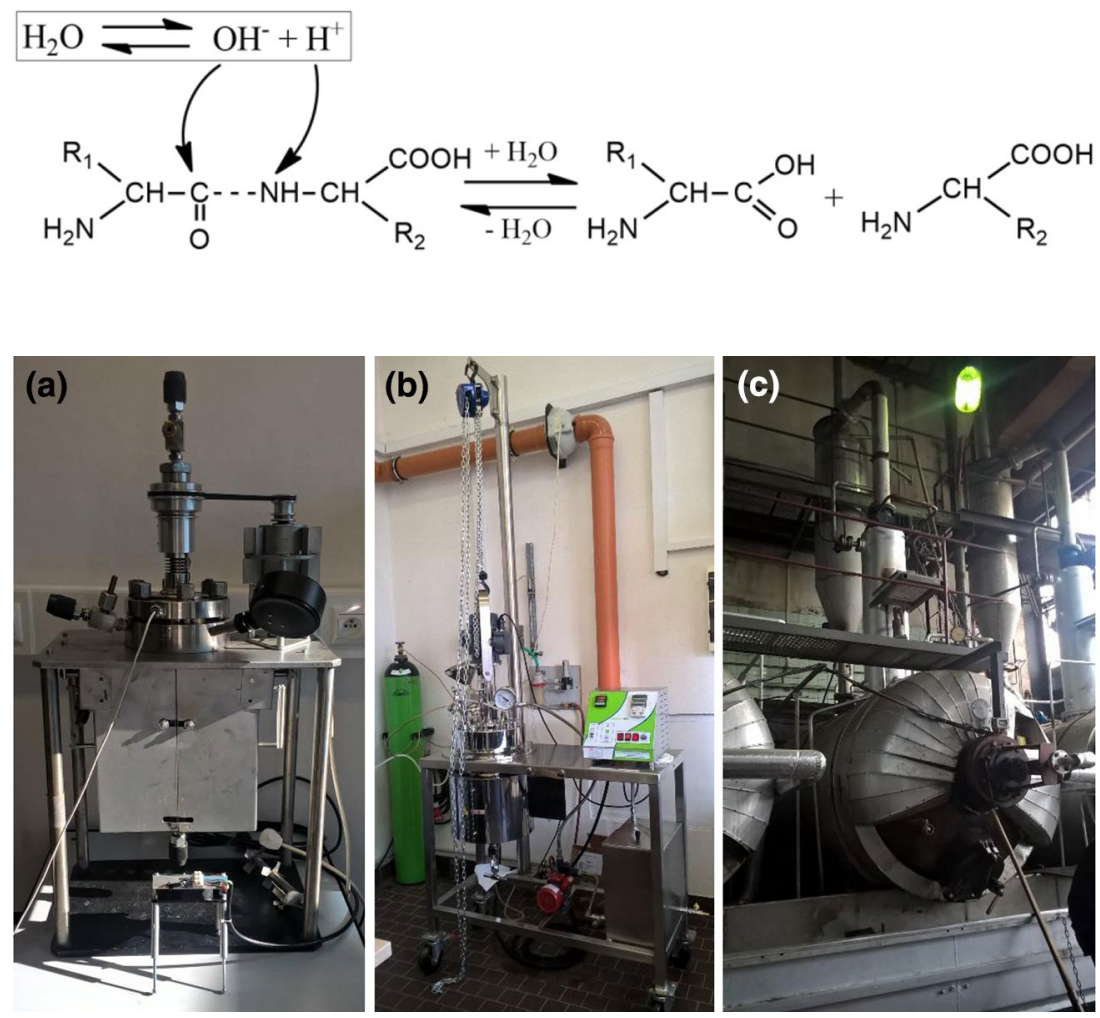

Fig. 2 Batch stirred reactors of the volume of a $2 \mathrm{~L}, \mathbf{b} 25 \mathrm{~L}$ (with control and cooling units) and $\mathbf{c} 8000 \mathrm{~L}$
Table 1 The chicken feathers and malic acid concentrations per $1 \mathrm{~L}$ water for individual reactors

\begin{tabular}{llll}
\hline Reactor scale & Laboratory & Semi pilot & Plant operation \\
\hline Feathers $(\mathrm{g} / \mathrm{L})$ & 100 & 133 & 136 \\
Malic acid $(\mathrm{g} / \mathrm{L})$ & 7 & 6.7 & 7.2 \\
\hline
\end{tabular}

Conditions of feather hydrolysis applied for individual reactors including their specifications are listed below.

(a) $2 \mathrm{~L}$ volume, blade stirrer $(500 \mathrm{rpm}): 1 \mathrm{~L}$ of water, $100 \mathrm{~g}$ of feathers, $7 \mathrm{~g}$ malic acid; $115^{\circ} \mathrm{C}, 5 \mathrm{~h}, 0.15 \mathrm{MPa}$

(b) $25 \mathrm{~L}$ volume, Rushton turbine $(400 \mathrm{rpm}): 15 \mathrm{~L}$ of water, $2 \mathrm{~kg}$ of feathers, $100 \mathrm{~g}$ malic acid, $139^{\circ} \mathrm{C}, 5 \mathrm{~h}$, $0.12 \mathrm{MPa}$

(c) $8000 \mathrm{~L}$ volume, radial flow agitator $(15 \mathrm{rpm}): 2500 \mathrm{~L}$ of water, $340 \mathrm{~kg}$ of feathers, $18 \mathrm{~kg}$ malic acid, $139^{\circ} \mathrm{C}$, $16 \mathrm{~h}, 0.25 \mathrm{MPa}$.

Comparable conditions of scale-up experiments are shown in Table 1.

Initially, all reactors were flushed with pressurized steam, and the batch was heated to the Temperature of $115-139{ }^{\circ} \mathrm{C}$ and pressurized up to $0.15-0.25 \mathrm{MPa}$ under constant stirring. The typical working time for the laboratory and semipilot reactors varied between 3 and $5 \mathrm{~h}$ (Solcova et al. 2019). The working time for the operational reactor consisted of two periods; heating period lasted for $6 \mathrm{~h}$ and cooling period to $100{ }^{\circ} \mathrm{C}$ for $10 \mathrm{~h}$. The hydrolysis reaction was running during both periods; thus, the total reaction time was $16 \mathrm{~h}$.

In all cases, waste chicken feathers (directly from production without any treatment) with water content of approximately 35 wt.\% (Rabbit Trhovy Stepanov, corp. Czech Republic) were used as a feedstock. The resulting product contained a liquid hydrolysate, and the solid residue was below 5\%. The chicken feathers, liquid hydrolysate and solid residue as a filter cake are shown in Fig. 3 for the reactor of $25 \mathrm{~L}$ volume.

\section{Process scale-up}

Scale-up of any process is really difficult and brings a lot of challenges. It is essential not only to ensure the speed and efficiency of the process, appropriate with the composition of the final product, but also consider process economy and ecology. For these reasons, the study is focused on the comparison of hydrolysate compositions for individual stages of scale-up, the economics of the process in the operating reactor of $8000 \mathrm{~L}$ volume, as well as reflecting the carbon footprint.

The composition of the hydrolysate (Stiborova et al. 2020), such as the proportion of the individual amino acids, the amount of peptides and proteins, the elemental composition belongs to the most important characteristics of the hydrolysate. 
Fig. 3 a Waste chicken feathers, b hydrolysate, filtrate $\mathbf{c}$ filter cake
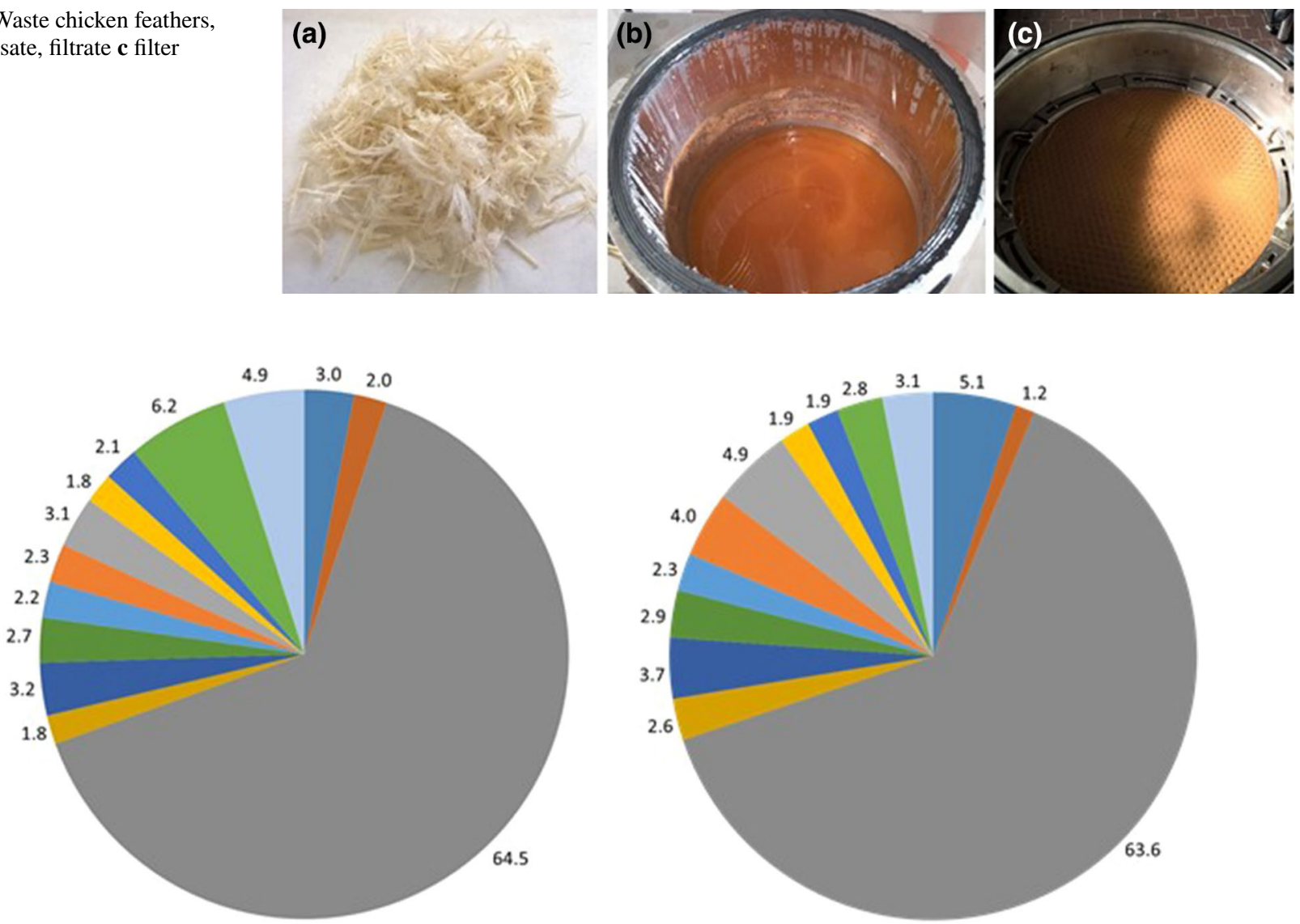

(a)

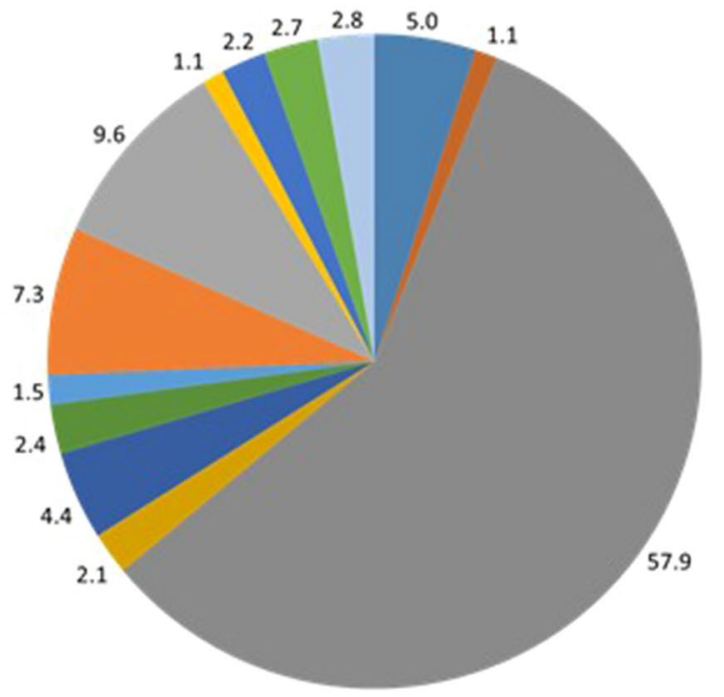

(b)

(c)

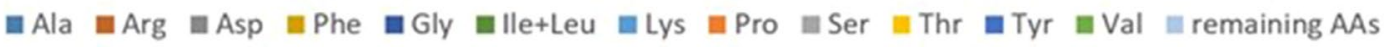

Fig. 4 Proportion of the individual amino acids: a the laboratory reactor $(2 \mathrm{~L}), \mathbf{b}$ the pilot reactor $(25 \mathrm{~L}), \mathbf{c}$ the operational reactor $(8000 \mathrm{~L})$

Proportions of the individual amino acids for laboratory, pilot and operational reactors are shown in Fig. 4. It is evident that the individual amino acid proportions of the total amino acids contents were nearly the same for laboratory and pilot reactors. In both reactors, aspartic acid was predominantly formed; $64 \%$ in the laboratory, $63.6 \%$ in the pilot reactor, and the amount of other amino acids varied only slightly-up to $6 \%$. Regarding the operational reactor, the 
proportion of aspartic acid decreased slightly to around 58\%, while the proportion of some other amino acids increased a little bit, e.g. serine up to $9.6 \%$, and proline up to $7.3 \%$.

It is obvious that the process scale-up and the reaction time did not affect the amino acid concentrations. This fact seems to be related to their limited solubility, which is only $4.5 \mathrm{~g} / \mathrm{L}$ at $20^{\circ} \mathrm{C}$ for aspartic acid in water (ILO and WHO 2017). In addition, this value may be lower in the complex environment of the hydrolyzate, which contains a number of proteins, peptides and lipid components such as free fatty acids and their glycerols derived from the simultaneous hydrolysis of keratin and fats present. The resulting reaction mixture contained amino acids and reaction products-proteins, peptides and also lipid components.

The results of protein and peptide analyses (Stiborova et al. 2020) of the pilot and operational hydrolysates showed that a significantly higher amount was found in the hydrolysate prepared in the operational reactor, namely $36.9 \mathrm{~g} / \mathrm{L}$ as distinct from $23.3 \mathrm{~g} / \mathrm{L}$ in the pilot hydrolysate; see Table 2. Probably, an essential role was played by the reaction time; $16 \mathrm{~h}$ compared to $5 \mathrm{~h}$.

The results of the elemental analysis for pilot and operational hydrolysates and filtration cakes are summarized in Table 3, where the weight amounts of the individual elements in hydrolysates and filtration cakes prepared in the pilot and the operating units are compared. Apparently, both hydrolysates, as well as the filtration cakes, contained not only the same elements but also nearly the same weight percentages of these elements.

Based on the presented results, it can be summarized that the scale-up of the new environmentally friendly method of physicochemical hydrolysis of waste feathers was successfully scaled-up, and it has all the prerequisites for processing large volumes of waste feathers. The basic precondition for the hydrolysate utilization, either as chondroprotectives or

Table 2 Composition of hydrolysate in individual reactors with respect to proteins and peptides

\begin{tabular}{ll}
\hline Autoclave type & $\begin{array}{l}\text { Sum of pep- } \\
\text { tides + proteins } \\
(\mathrm{g} / \mathrm{L})\end{array}$ \\
\hline Pilot unit & 23.3 \\
Operational unit & 36.9 \\
\hline
\end{tabular}

special fertilizers, is the economic evaluation of the process, including ecological impacts.

Life cycle analysis must be based on a precise description of individual process steps, which follow. $340 \mathrm{~kg}$ of waste chicken feathers were put into the reactor of the volume of $8000 \mathrm{~L}$ together with $18 \mathrm{~kg}$ of malic acid and $2500 \mathrm{~L}$ of water. The autoclave was washed with a pressure steam of $200{ }^{\circ} \mathrm{C}$, and under constant mixing, the batch was heated to $139{ }^{\circ} \mathrm{C}$ and the pressure set to $0.26 \mathrm{MPa}$. Under these conditions, the reaction mixture was maintained for $6 \mathrm{~h}$, and then the reaction mixture was cooled slowly to $100{ }^{\circ} \mathrm{C}$ for $10 \mathrm{~h}$. Throughout the cooling period, the hydrolytic reaction took place in the system as well, leading to a high conversion of the biomass intake at the total reaction time of $16 \mathrm{~h}$.

\section{Life cycle analysis}

A comparative life cycle analysis (LCA) (Campos et al. 2020) was performed in the openLCA software (GreenDelta, Germany) using the ecoinvent v.3.6 database (Ecoinvent, Switzerland). The APOS unit model was decided to be used as it follows the attributional approach in which burdens are attributed proportionally to specific processes. For the life cycle impact assessment (LCIA) was chosen one of the most common methods-the CML baseline v.4.4 (University of Leiden, the Netherlands), which contains the basic impact category group such as acidification, climate change, human toxicity, ecotoxicity (Guinee et al. 2002).

The inputs and outputs, recalculated to the production of $1 \mathrm{~L}$ hydrolysate, included in the LCA assessment, are given in Table 4. It can be seen, that minimal variations are among the assessed reactors. The only one factor, the electricity usage, shows significant decrease from the laboratory to the operational reactor due to the most optimized operating mode of this process. To optimize the process further, also a variant with the usage of natural gas for the operational reactor heating was considered.

Basing on the achieved results, it can be seen that the environmental impacts of the feather hydrolysis process are the most significant at the laboratory scale reactor. At the operation scale is significantly lower, mainly due to abovementioned optimization of electricity usage in this process as the electricity usage is the most contributing aspect of the feather hydrolysis process, followed by the production
Table 3 Elemental analysis (wt.\%) of hydrolysates and filtration cakes

\begin{tabular}{lllllllllll}
\hline Product/element & Reactor $^{\mathrm{a}}$ & $\mathrm{C}$ & $\mathrm{N}$ & $\mathrm{O}$ & $\mathrm{Na}$ & $\mathrm{P}$ & $\mathrm{S}$ & $\mathrm{Cl}$ & $\mathrm{K}$ & $\mathrm{Ca}$ \\
\hline Hydrolysate & PR & 44.0 & 14.2 & 39.1 & 0.2 & 0.2 & 1.5 & 0.3 & 0.2 & 0.3 \\
& $\mathrm{OR}$ & 40.7 & 15.5 & 42.6 & 0.3 & 0.0 & 0.5 & 0.1 & 0.1 & 0.2 \\
Filtration cake & PR & 52.9 & 14.2 & 30.3 & 0.1 & 0.2 & 2.1 & 0.1 & 0.0 & 0.1 \\
& OR & 52.4 & 13.2 & 32.4 & 0.0 & 0.5 & 1.2 & 0.1 & 0.1 & 0.1 \\
\hline
\end{tabular}

${ }^{a} P R$ Pilot reactor, $O R$ operational reactor 
Table 4 Operational inputs and outputs parameters related to $1 \mathrm{~L}$ hydrolysate (all reactors)

\begin{tabular}{|c|c|c|c|c|c|}
\hline Inputs & Unit & Laboratory & Pilot & Operational E & Operational G \\
\hline Water & $\mathrm{L}$ & 0.95 & 0.97 & 0.92 & 0.92 \\
\hline Chicken feather & $\mathrm{Kg}$ & 0.10 & 0.08 & 0.13 & 0.13 \\
\hline Malic acid & g & 6.65 & 3.88 & 6.63 & 6.63 \\
\hline Electricity & $\mathrm{kWh}$ & 69.87 & 4.16 & 0.20 & 0.03 \\
\hline Natural gas & $\mathrm{m}^{3}$ & - & - & - & 0.024 \\
\hline Outputs & Unit & Laboratory & Pilot & Operational E & Operational G \\
\hline Liquid hydrolysate & $\mathrm{L}$ & 1 & 1 & 1 & 1 \\
\hline Waste filter cake & $\mathrm{Kg}$ & 0.052 & 0.053 & 0.053 & 0.053 \\
\hline
\end{tabular}

Operational E—only electricity is used; operational $G$ —natural gas is used for reactor heating, electricity for steering

of used malic acid. It is even lower for the considered combination of gas/electricity.

Table 5 shows the LCIA results of the project variants. Each selected LCIA category is displayed in the rows and the project variants in the columns. The unit is the unit of the LCIA category as defined in the LCIA method.

The following Fig. 5 gives the relative indicator results of the respective project variants. For each indicator, the maximum result is set to $100 \%$ and the results of the other variants are displayed in relation to this result.

From the point of view of individual environmental indicators, the most contributing was the depletion of abiotic sources (fossil fuels consumption) and the climate change in all process scales, which are again connected to the electricity used. As the electricity, production mix, $\mathrm{CZ}$ was considered during this LCA study, these impacts could be reduced by using some other electricity sources, such as natural gas (the variant operational G) or photovoltaics or wind, which are commercially accessible in the Czech Republic. The environmental impact of the feather hydrolysis process could be further enhanced by a valorisation of the produced waste sludge.

\section{Economic analysis}

The vast majority of feathers end up in landfills without further use, although simple landfilling of feathers is associated with a risk of soil and water pollution (Prasanthi et al. 2016). At present, therefore, feathers can clearly be considered as waste for which the costs of its disposal are borne by the chicken producer. From this point of view, it would then be possible to obtain feathers for the hydrolysis process at a negative price, which would achieve a limited amount of cost savings for landfilling feathers as waste. As soon as the use of feathers for the production of products such as hydrolysate or aspartic acid starts commercially, the feathers cease to be waste, but a raw material that (necessarily) is needed by manufacturers. This in turn means that chicken producers will want to share in the economic effects of feather processing. If there is sufficient demand for chicken feathers, this

Table 5 LCIA results

\begin{tabular}{|c|c|c|c|c|c|}
\hline Indicator & Unit/kg-eq & Laboratory & Pilot & Operational E & Operational G \\
\hline Acidification potential (average Europe) & $\mathrm{SO}_{2}$ & $2.227 \times 10^{-1}$ & $1.334 \times 10^{-2}$ & $7.663 \times 10^{-4}$ & $2.329 \times 10^{-4}$ \\
\hline Climate change (GWP100) & $\mathrm{CO}_{2}$ & 63.65 & 3.797 & 0.195 & $4.447 \times 10^{-2}$ \\
\hline Depletion of abiotic resources (elements) & $\mathrm{Sb}$ eq & $1.018 \times 10^{-6}$ & $6.408 \times 10^{-8}$ & $9.406 \times 10^{-9}$ & $6.998 \times 10^{-9}$ \\
\hline Depletion of abiotic resources (fossil fuels) & MJ & $5.567 \times 10^{2}$ & 33.342 & 1.962 & 1.494 \\
\hline Eutrophication (generic) & $\mathrm{PO}_{4}^{3-}$ & 0.338 & $2.017 \times 10^{-2}$ & $1.021 \times 10^{-3}$ & $2.002 \times 10^{-4}$ \\
\hline Freshwater aquatic ecotoxicity (FAETP inf) & 1.4-DCB & 55.45 & 3.308 & 0.171 & $3.630 \times 10^{-2}$ \\
\hline Human toxicity (HTP inf) & 1.4-DCB & 37.11 & 2.220 & 0.1245 & $3.907 \times 10^{-2}$ \\
\hline Marine ecotoxicity (MAETP inf) & 1.4-DCB & $1.484 \times 10^{5}$ & $8.845 \times 10^{3}$ & $4.414 \times 10^{2}$ & 86.783 \\
\hline Ozone layer depletion (ODP steady state) & CFC-11 & $3.312 \times 10^{-6}$ & $2.003 \times 10^{-7}$ & $1.525 \times 10^{-8}$ & $1.275 \times 10^{-8}$ \\
\hline Photochemical oxidation (high $\mathrm{NO}_{\mathrm{x}}$ ) & Ethylene & $8.490 \times 10^{-3}$ & $5.089 \times 10^{-4}$ & $3.070 \times 10^{-5}$ & $1.075 \times 10^{-5}$ \\
\hline Terrestrial ecotoxicity (TETP inf) & 1.4-DCB & $9.940 \times 10^{-2}$ & $6.066 \times 10^{-3}$ & $5.612 \times 10^{-4}$ & $3.332 .10^{-4}$ \\
\hline
\end{tabular}

Operational E—only electricity is used; operational $G$-natural gas is used for reactor heating, electricity for steering 


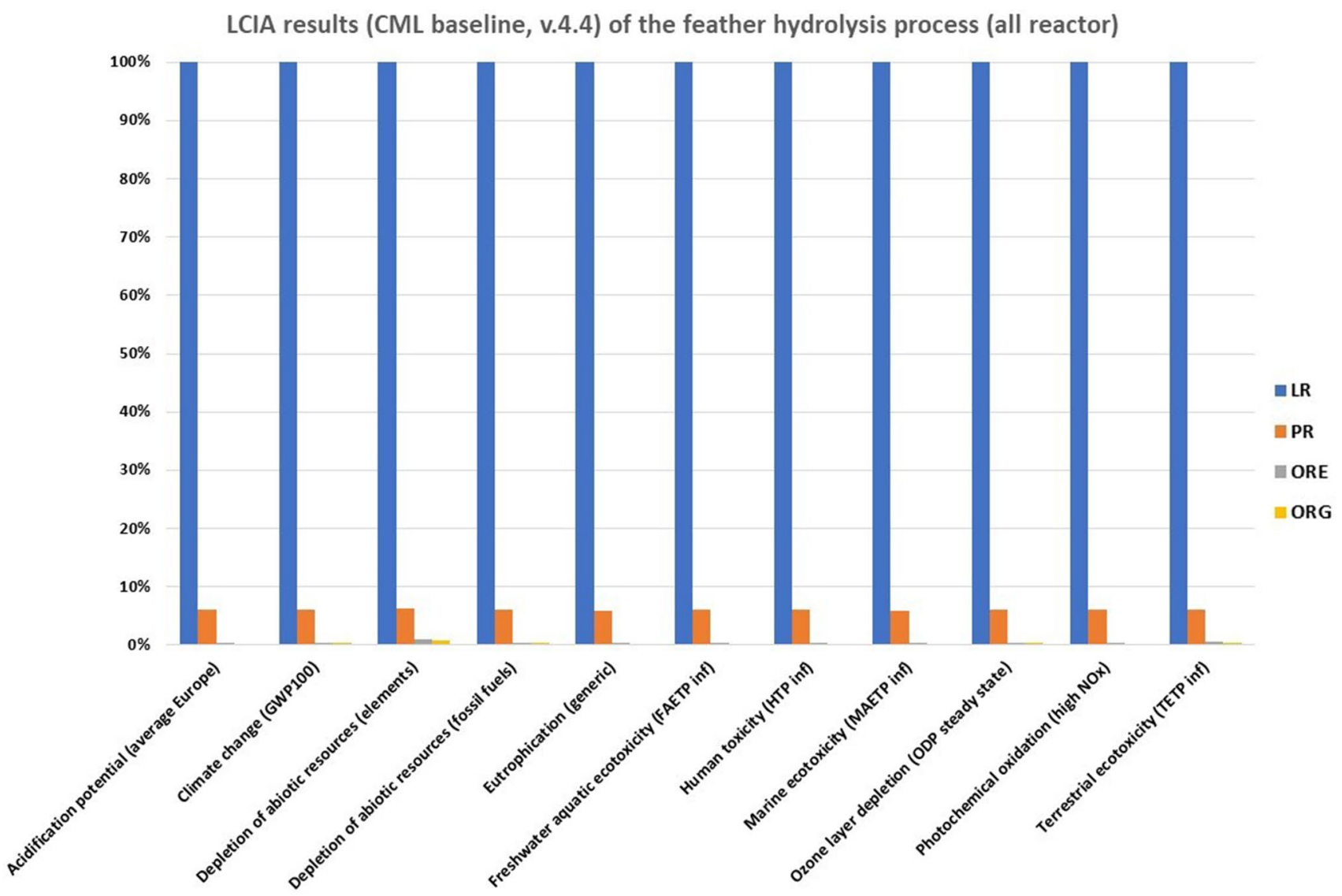

Fig. 5 Comparison of the relative indicator results (all reactor). $L R$ Laboratory reactor, $P R$ pilot reactor, $O R E$ operational reactor-electricity only, $O R G$ operational reactor-gas used for heating

will create pressure to increase the economic value of feathers as a raw material. Chicken producers will not want to pay the (original) amounts for the disposal of feathers, but will accept, for example, only a zero payment for the collection of feathers, or will even want to pay for it.

The basic economic evaluation of the efficiency of feather hydrolysis is based on the process analysis of the technology, on the identification of the necessary technological, material and energy inputs, and at the same time on the identification of the type of output products.

The process of feather hydrolysis, which ends with the production of hydrolysate, can be divided into the following parts:

1. Transport of feathers from slaughterhouses + storage at the place of processing

2. Preparation of the input (reaction) mixture

3. Radial flow agitator-own reaction

4. Pumping of the produced hydrolysate, storage and distribution
Cost analysis of any product can be performed from several different perspectives-for example, from the point of view of total production costs (including production, sales and business overheads) or from the point of view of direct production costs only. In the case of the development of a new technology and the assessment of its economic viability, the key aspect is the analysis of direct costs and all cost inputs directly caused by the production process using the given technology.

The direct costs of the assessed process can be divided into the costs of ensuring the operation of the plant (OPEX) and the costs of acquiring the equipment for the production of hydrolysate (CAPEX).

The basic energy and material cost inputs, which form a significant part of OPEX, are summarized in Table 6.

Feathers (untreated) including transport are estimated at zero cost, but their cost evaluation can be very variablesee above. Steam for preparation (rinsing) radial flow agitator (other cost item) is obtained either from its own energy management or is produced for the purposes of the process, for example, using an electric steam generator, the price of technological steam can be estimated at about 16-20 EUR/ 
Table 6 Overview of direct material and energy cost for the process per batch

\begin{tabular}{llllll}
\hline Input & Amount & Input & Amount & Input & Amount \\
\hline Feathers (kg) & 340 & Water $\left(\mathrm{m}^{3}\right)$ & 2.5 & Malic acid (kg) & 18 \\
Feathers (EUR) & 0 & Water (EUR) & 4 & Malic acid (EUR) & 75 \\
Natural gas (MWh) & 0.71 & Electricity (kWh) & 100 & Other cost (EUR) & 2 \\
Natural gas (EUR) & 27.7 & Electricity (EUR) & 8 & - & - \\
Total direct material and & 116.7 & - & - & - & - \\
$\begin{array}{l}\text { energy cost per batch } \\
\text { (EUR) }\end{array}$ & & & & \\
\hline
\end{tabular}

Natural gas is assumed to heat the reactor. If only electricity would be used, overall electricity consumption would be (assuming its efficiency of utilization compared with the natural gas) app. $550 \mathrm{kWh}$
GJ (supply from external distribution), the price may vary significantly from location to location. To heat the reaction mixture with a total weight of about $2850 \mathrm{~kg}$ to the reaction temperature and to cover heat losses during the first phase of the process $(6 \mathrm{~h})$, about $0.71 \mathrm{MWh}$ of heat in natural gas is needed. Cost of energy for heating can be valued using the price of natural gas in the amount of approx. 34-40 EUR/ MWh (price estimate for the customer/entrepreneur) with consumption higher than $63 \mathrm{MWh} /$ year (SunTanzer 2020). Cost of electricity for technology operation is based on cost valuation at the level of the market price of electricityapprox. 70-80 EUR/MWh (consumption from $22 \mathrm{kV}$ ).

\section{Note}

- The above prices are based on estimates of current prices for small and medium-sized Enterprises and the price level of 2020.

- $\mathrm{CZK} / \mathrm{EUR}=25$

All of the above OPEX items are in annual value directly proportional to the amount of feathers processed. $340 \mathrm{~kg}$ of feathers are placed in one batch, the whole production process, including the time for handling the product and feathers, is about $24 \mathrm{~h}$. The direct reaction time is $16 \mathrm{~h}(6 \mathrm{~h}$ at operating temperature, $10 \mathrm{~h}$ cooling), to which must be added the time required to clean the radial flow agitator and prepare another batch. The total time of one production phase can thus be estimated (for the considered radial flow agitator with a volume of $8000 \mathrm{~L}$ ) at $24 \mathrm{~h}$. With an estimated annual use of the technology of 200 batches, a total of 68 tonnes of feathers are processed, i.e. $0.45 \%$ of the total estimated amount of chicken feathers in the Czech Republic.

Other direct items of OPEX include personnel costs of employees involved in their own process, from the receipt of the input raw material (feathers) to the dispatch of the output raw material-hydrolysate. The time of the reaction process is included in the cost calculation only with a small part of the capacity of the staff supervising the process. The amount of allocated work will vary greatly depending on the conditions of implementation in individual production facilities. The amount of personnel costs can be estimated according to the current amount of the average wage in the Czech Republic-1360 EUR in 2020, which after taking into account health and social insurance and after recalculating the average number of working hours per month gives about 11 EUR/hour of personnel costs. If we would estimate the total labour time needed per one batch between 5 and $10 \mathrm{~h}$, Then estimate of labour total cost would be app. 55-110 EUR/batch.

The costs of storing feathers and storing the final product can be neglected in relation to other OPEX items, as well as CAPEX.

From the CAPEX point of view, the key device is a radial flow agitator. Its price can be estimated at about 200 thousand. EUR, the service life is 10 years.

For a basic assessment of the economic efficiency of the feather hydrolysis technology itself, it is appropriate to use the levelized cost-LC method (OpenEI 2020). The basic formula for LC is:

$\mathrm{LC}=\frac{\mathrm{CRF}_{i, T} \times \mathrm{CAPEX}+\mathrm{OPEX}}{Q}$

where $i$, expected rate of return on technology investment [\%]; $T$, number of years of technology lifetime [-]; CRF, capital recovery factor [-]; CAPEX, technology acquisition costs [EUR]; OPEX, annual operating expenses for a given production size $Q$ [EUR]; $Q$, annual product production [t].

The formula of levelized cost assumes constant prices and does not calculate with taxation and the way of financing. CAPEX is turned into annual payments with a Capital Recovery Factor. In principle, levelized costs are not mere (accounting) costs, because they also include the expected rate of return on investment. For basic indicative calculations, the rate of return (when calculated at constant prices excluding inflation) can be estimated at 10-12\% (which roughly corresponds to the average profitability of Czech industrial enterprises-(Ministry of Industry and Trade 
Table 7 Overview of cost estimates of feather hydrolysis per batch

\begin{tabular}{ll}
\hline Cost item & EUR \\
\hline OPEX - material and energy & 117 \\
OPEX—direct labour & $55-110$ \\
CAPEX & $163-177$ \\
TOTAL & $335-404$ \\
\hline
\end{tabular}

If electricity would be used instead of natural gas for heating the reactor $O P E X$ - material and energy cot would increase to 118 EUR

2018). This, together with the assumption of a 10-year life, leads to a CRF value of 0.1627-0.177 and an annual fixed cost of investment in the radial flow agitator of EUR $32,500-35,400 /$ year. Assuming 200 batches per year, the fixed costs per batch would be about 162.5-177 EUR.

From the above OPEX values, the amount of material and energy cost per batch can be estimated as approximately EUR 117. The two decisive items (if we consider the price of feathers at zero) are the cost of malic acid (this is the decisive item) and the cost of heating the radial flow agitator. The total amount of costs per batch (assuming 200 batches per year) is then approximately 280-294 EUR + estimate of direct labour cost-see Table 7 . This value can then be recalculated to $1 \mathrm{~kg}$ of the output product-hydrolysate.

The presented economic analysis captures only the direct costs of processes directly related to the processing of feathers and the production of hydrolysate. The analysis does not include other costs related to the overhead costs of the processing company, nor the costs of further processing of the hydrolysate and its distribution to end customers. The above analysis serves primarily to provide a basic assessment of the possible economic viability of a given feather hydrolysis upscaling technology. At the same time, the analysis serves to identify key cost items in order to optimize their amount.

\section{Conclusion}

The newly designed environmentally friendly method of waste feather hydrolysis was successfully scaled-up to $8000 \mathrm{~L}$, which enables processing of large feather volumes. Scaling up the whole process leads to a significant reduction in the direct cost of processing feathers. Assuming a total of 200 batches processed per year (each batch of $340 \mathrm{~kg}$ of processed feathers), the total direct costs calculated using the levelized cost method are around EUR 280-294 per batch + direct labour cost. Key input parameters influencing costs include the cost of the technology itself, the malic acid, the cost of process heat and. the input material-feathers.

The similar conclusion was confirmed during the LCA analysis, the scaling up the whole process helped to reduce the process environmental burden, caused mainly by the usage of the conventional electricity mix. If green energy sources, such photovoltaics or wind, or even natural gas are used, the environmental impact of the feather hydrolysis process will be significantly lower.

Acknowledgement Financial support from the Technology Agency of the Czech Republic under the National Competence Centre Biocirtech (Project No. TN010000048) is acknowledged.

\section{Declaration}

Conflict of interest The authors declare that they have no known competing financial interest or personal relationships that could have appeared to influence the work reported in this paper.

Open Access This article is licensed under a Creative Commons Attribution 4.0 International License, which permits use, sharing, adaptation, distribution and reproduction in any medium or format, as long as you give appropriate credit to the original author(s) and the source, provide a link to the Creative Commons licence, and indicate if changes were made. The images or other third party material in this article are included in the article's Creative Commons licence, unless indicated otherwise in a credit line to the material. If material is not included in the article's Creative Commons licence and your intended use is not permitted by statutory regulation or exceeds the permitted use, you will need to obtain permission directly from the copyright holder. To view a copy of this licence, visit http://creativecommons.org/licenses/by/4.0/.

\section{References}

Ansarullah RR, Kusno A, Baharuddin JN (2018) Utilization of waste of chicken feathers and waste of cardboard as the material of acoustic panel maker. IOP Conf Ser Earth Environ Sci 126:012036. https:// doi.org/10.1088/1755-1315/126/1/012036

Bouhamed SBH, Kechaou N (2017) Kinetic study of sulphuric acid hydrolysis of protein feathers. Bioproc Biosyst Eng 40(5):715721. https://doi.org/10.1007/s00449-017-1737-7

Campos I, Pinheiro Valente LM, Matos E, Marques P, Freired F (2020) Life-cycle assessment of animal feed ingredients: poultry fat, poultry by-product meal and hydrolyzed feather meal. J Clean Prod 252:119845. https://doi.org/10.1016/j.jclepro.2019.119845

Guinee JB, Gorree M, Heijungs R, Huppes G, Kleijn R, Koning A de, Oers L van, Wegener Sleeswijk A, Suh S, Udo de Haes HA, Bruijn H de, Duin R van, Huijbregts MAJ (2002) Handbook on life cycle assessment. Operational guide to the ISO standards. I: LCA in perspective. IIa: Guide. IIb: Operational annex. III: Scientific background. Kluwer Academic Publishers, Dordrecht. ISBN 1-4020-0228-9

Hanika J, Rouskova M, Sabata S, Jandejsek Z, Fulin T, Jiru M, Solcova O (2019) Pressure hydrolysis of wastes from chicken feathers cartilage and feathers. In: Solcova O, Hanika J, Topka P (eds) Biorefining in the 21st century. ICPF CAS Prague, pp 74-79 (ISBN: 978-80-86186-02-3)

Hanika J, Solcova O, Rouskova M, Sabata S, Jandejsek Z, Fulin T, Hajslova J, Stranska M, Jiru M, Kastanek P, Kronusova O (2019) A method for the hydrolysis of protein biomass, a liquid hydrolysate prepared in this way and their use. CZ Pat. 307856 , PV2018-472

ILO and WHO (2017) ICSC 1439-L-ASPARTIC ACID. inchem.org, EC Number: 200-291-6. http://www.inchem.org/documents/icsc/ icsc/eics 1439 .htm 
Joardar JC, Rahman MM (2018) Poultry feather waste management and effects on plant growth. Int J Recycl Org Waste Agric 7:183-188. https://doi.org/10.1007/s40093-018-0204-z

Kaewsalud T, Yakul K, Jantanasakulwong K, Tapingkae W, Watanabe M, Chaiyaso T (2020) Biochemical characterization and application of thermostable-alkaline keratinase from Bacillus halodurans SW-X to valorize chicken feather wastes. Waste Biomass Valor. https://doi.org/10.1007/s12649-020-01287-9

Kanani F, Davoud Heidari M, Gilroyed BH, Pelletier N (2020) Waste valorization technology options for the egg and broiler industries: a review and recommendations. J Clean Prod 262:121129. https:// doi.org/10.1016/j.jclepro.2020.121129

Kumar EV, Srijana M, Chaitanya K, Reddy YHK, Reddy G (2011) Biodegradation of poultry feathers by a novel bacterial isolate Bacillus altitudinis GVC11. Indian J Biotechnol 10:502-507

Ministry of Agriculture of the Chech Republic (2017) Situational and outlook report-poultry and eggs. Prague. ISBN 978-80-7434506-7. http://eagri.cz/public/web/file/624527/Drubez_2018_Web. pdf

Ministry of Industry and Trade of the Czech Republic (2018). Financial analysis of business sphere for 2017. Prague. https://www.mpo.cz/ assets/cz/rozcestnik/analyticke-materialy-a-statistiky/analytickematerialy/2018/6/FA2017.pdf

Nahm BA, Nahm KH (2004) Poultry production and waste management hardcover. Ju Han Publ. Rep. Korea

Narcos J (2020) Imperial student start-up finds new use for waste feathers. Imperial College, London

OpenEI (2020) Levelized cost calculation. https://openei.org/apps/ TCDB/levelized_cost_calculations.html

Pahua-Ramos ME, Hernandez-Melchor DJ, Camacho-Pérez B, Quezada-Cruz M (2017) Degradation of chicken feathers: a review. Biotechnol Ind J 13(6): 1-24

Prasanthi N, Bhargavi S, Machiraju PVS (2016) Chicken feather waste- a threat to the environment. Int J Innov Res Sci Eng Technol 5(9):2319-8753
Sharma S, Gupta A, Nadda AK, Chua GK, Kamyab H, Saufi SM (2018) An efficient conversion of waste feather keratin into ecofriendly bioplastic film. Clean Technol Environ Policy 20:2157-2167. https://doi.org/10.1007/s10098-018-1498-2

Sinkiewicz I, Staroszczyk H, Sliwinska A (2018) Solubilization of keratins and functional properties of their isolates and hydrolysates. J Food Biochem. https://doi.org/10.1111/jfbc.12494

Solcova O, Hanika J, Topka P (Eds) (2019) Biorefining in the 21st Century, 70-80, 97-98. ISBN: 978-80-86186-02-03

Stiborova H, Kronusova O, Kastanek P, Brazdova L, Lovecka P, Jiru M, Belkova B, Poustka J, Stranska M, Hajslova J, Demnerova K (2020) Waste products from the poultry industry: a source of high-value dietary supplements. J Chem Technol Biotechhnol 95(4):985-992. https://doi.org/10.1002/jctb.6131

SunTanzer (2020) Gas price list. https://www.stenergy.cz/wp-content/ uploads/2019/12/Ceni\%CC\%81k-ZP_Podnikatele\%CC\%81-2020GasNet.pdf

Tesfaye T, Sithole B, Ramjugernath D (2017) Valorisation of chicken feathers: a review on recycling and recovery route-current status and future prospects. Clean Technol Environ 19:2363-2378. https://doi.org/10.1007/s10098-017-1443

Tesfaye T, Sithole B, Ramjugernath D, Chunilall V (2017) Valorisation of chicken feathers: characterisation of physical properties and morphological structure. J Clean Prod 149:349-365. https://doi. org/10.1016/j.jclepro.2017.02.112

Windhorst HW (2018) Patterns of EU poultry meat production and consumption—a 2016 status report. University of Vechta

Publisher's Note Springer Nature remains neutral with regard to jurisdictional claims in published maps and institutional affiliations.

\section{Authors and Affiliations}

\section{Olga Solcova ${ }^{1}$ (D Jaroslav Knapek ${ }^{2} \cdot$ Lenka Wimmerova $^{3} \cdot \mathrm{Kamila}$ Vavrova $^{4} \cdot$ Tomas Kralik $^{2} \cdot$ Milena Rouskova $^{1}$. Stanislav Sabata ${ }^{1}$. Jiri Hanika ${ }^{1}$}

\author{
Jaroslav Knapek \\ knapek@fel.cvut.cz \\ Lenka Wimmerova \\ wimmerova@fzp.czu.cz \\ Kamila Vavrova \\ vavrova@vukoz.cz \\ Tomas Kralik \\ tomas.kralik@fel.cvut.cz \\ Milena Rouskova \\ rouskova@icpf.cas.cz \\ Stanislav Sabata \\ sabata@icpf.cas.cz
}

Jiri Hanika

hanika@icpf.cas.cz

1 Institute of Chemical Process Fundamentals of the CAS, Prague, Czech Republic

2 Faculty of Electrical Engineering, CTU in Prague, Prague, Czech Republic

3 Faculty of Environmental Sciences, Czech University of Life Sciences Prague, Prague, Czech Republic

4 Silva Taroucy Research Institute for Landscape and Ornamental Gardening, Průhonice, Czech Republic 